\title{
Evaluation of Quantitative Phytochemicals, Liver Enzymes and Histological Changes in Isoniazid Induced Hepatotoxicity in Adult Male Wistar Rats Treated with Aqueous Extracts of Brysocarpus coccineus
}

\author{
Kashini Andrew1, Nachamada Solomon Emmanuel1, Deborah Chioma Ejiogu', \\ Chinonso Nicodemus Chima', Fatima Mohammed Yahuza ${ }^{1}$, \\ Emmanuel Chukwuemeka Umeh ${ }^{2}$, Philemon Paul Mshelia ${ }^{2 *}$ \\ ${ }^{1}$ Department of Human Physiology, Faculty of Basic Medical Sciences, College of Medical Sciences, Ahmadu Bello University \\ Zaria, Nigeria \\ ${ }^{2}$ Department of Human Physiology, College of Medical Sciences, Abubakar Tafawa Balewa University, Bauchi, Nigeria \\ Email: *senachamada2@gmail.com
}

How to cite this paper: Andrew, K., Emmanuel, N.S., Ejiogu, D.C., Chima, C.N., Yahuza, F.M., Umeh, E.C. and Mshelia, P.P. (2017) Evaluation of Quantitative Phytochemicals, Liver Enzymes and Histological Changes in Isoniazid Induced Hepatotoxicity in Adult Male Wistar Rats Treated with Aqueous Extracts of Brysocarpus coccineus. Advances in Enzyme Research, 5, 33-44. https://doi.org/10.4236/aer.2017.53004

Received: July 28, 2017

Accepted: September 19, 2017

Published: September 22, 2017

Copyright (c) 2017 by authors and Scientific Research Publishing Inc. This work is licensed under the Creative Commons Attribution International License (CC BY 4.0).

http://creativecommons.org/licenses/by/4.0/

\begin{abstract}
Isoniazid induced hepatotoxicity is a major concern in patients taking anti tuberculosis treatment and prophylaxis. It can result in elevated serum liver enzymes and hepatic failure. The aim of the study was to evaluate the phytochemicals and ameliorative effects of aqueous extracts of Brysocarpus coccineus on serum liver enzymes in isoniazid (INH) induced hepatotoxicity in adult male Wistar rats. Thirty six (36) adult male Wistar rats were divided into six groups of six rats each and were treated orally for 30 days as follows: Group I: $1 \mathrm{ml} / \mathrm{kg}$ of distilled water; group II: Isoniazid $(27 \mathrm{mg} / \mathrm{kg})$; group III: Isoniazid $(27 \mathrm{mg} / \mathrm{kg})+$ Livolin forte $(20 \mathrm{mg} / \mathrm{kg})$; group IV: Isoniazid $(27$ $\mathrm{mg} / \mathrm{kg})+$ B. coccineus $(200 \mathrm{mg} / \mathrm{kg})$; group V: Isoniazid $(27 \mathrm{mg} / \mathrm{kg})+$ B. coccineus $(400 \mathrm{mg} / \mathrm{kg})$; group VI: Isoniazid $(27 \mathrm{mg} / \mathrm{kg})+$ B. coccineus $(800 \mathrm{mg} / \mathrm{kg})$. At the end of the experiments, the Wistar rats were sacrificed and sera obtained for liver enzymes assay, whereas the liver tissue was also harvested and used for histological studies. Tanins, saponins, alkaloids and flavonoids were quantitatively present at $2.29 \%, 18.05 \%, 23.24 \%$ and $18.99 \%$, respectively. There was an increase in the serum AST and ALT in the isoniazid treated group, which was reversed by livolin forte and the aqueous extracts at a dose of $200 \mathrm{mg} / \mathrm{kg}$, however the extracts increased the serum levels of AST and ALT at higher doses, which was however not significant $(p>0.05)$ when compared to the controls. There was evidence of a reduction in hepatocytes
\end{abstract}


damage in the extract treated groups when compared to the Isoniazid untreated group. In conclusion, aqueous extracts of $B$. coccineus shows hepatoprotective effects at $200 \mathrm{mg} / \mathrm{kg}$ in isoniazid hepatotoxicity in adult male Wistar rats.

\section{Keywords}

Brysocarpus coccineus, Isoniazid, Hepatotoxicity, Phytochemicals

\section{Introduction}

Anti-Tuberculosis drug-induced liver injury (ATDILI) is the most prevalent drug-induced hepatotoxicity in Taiwan, China, South Africa and many other areas, which may both threaten patients' health and hinder the treatment of Tuberculosis (TB). Hence attempts at ameliorating this potentially grave drug-induced liver injury (DILI) are crucial. The three common first-line drugs for TB are isoniazid, rifampicin and pyrazinamide, which have the potential to induce liver damage [1] [2]. Anti-tuberculosis drug-induced liver injury (ATDILI) ranges from mild to severe forms, and can even be fatal. The incidence of ATDILI depends on different anti-tuberculosis regimens, definitions of liver injury and ethnic populations. Generally, $10 \%-20 \%$ of patients may have elevation of serum aminotransferase during administration of these drugs. Approximately $1 \%$ of patients may develop overt hepatitis, defined as symptomatic hepatotoxicity with jaundice, and significant elevation of serum aminotransferase. The mortality rate of patients with overt hepatitis is estimated to be around 10\% [2].

Isoniazid is primarily cleared through acetylation by $\mathrm{N}$-acetyltransferase 2 (NAT2) in the liver, resulting in acetylisonazid which is then hydrolysed to isonicotinic acid and monoacetylhydrazine (MAH). INH also undergoes hydrolysis catalysed by isoniazid hydrolase and forms hydrazine, which is then metabolised to MAH by NAT2. MAH can be acetylated to diacetylhydrazine which is non-toxic, or oxidised by cytochrome (CYP2E1) into hepatotoxic intermediates (Ching, 2011). Acetylhydrazine can be hydrolysed to hydrazine which may further induce CYP2E1, increasing the production of toxic metabolites. Hydrazine, MAH and isonicotinic acid are potentially hepatotoxic metabolites of INH and accumulation of these reactive metabolites in patients may cause serious adverse drug reactions. Administration of acetylhydrazine or acetylisoniazid in rats leads to the production of reactive alkylating species and covalent binding to liver proteins, causing hepatocyte injury manifesting as hepatocyte necrosis, sinusoidal dilatation and infiltration by inflammatory cells. NAT2, the major known enzyme involved in the metabolic pathway of INH and metabolites is suggested to play an important role in INH-induced hepatotoxicity, particularly the NAT2 slow acetylator genotypes/phenotypes [3].

Traditional medicine practice is an important source of livelihood and major source of income to about 200,000 traditional medicine practitioners in Nigeria; 
most of them rely on medicinal plants as their primary source of medicines. In many countries modern medicine has replaced traditional medicine with many synthetic products but almost $30 \%$ of pharmaceutical preparations are still obtained directly from plants. A large number of studies have been carried out on herbal traditional medicines and significant amount of laboratory data have been generated on their efficiency [4] [5].

Byrsocarpus coccineus Schum. and Thonn. (Connaraceae), a scandent shrub widely distributed in tropical Africa, is used in ethnomedicine to manage many illnesses. In Northern Nigeria, it is referred to by the Hausas as "Tsamiyar kasa or kimbar maharba". The Fulani people call it "wangarabubi or yangara-bubihi", while the Bassange people call it "Kogi". In the southern part of Nigeria the Yoruba people call it "Oke abolo" or "Mybo-apepea" [6]. Kilba people in Adamawa State call it 'mblakiki'. Byrsocarpus coccineus have been shown to be useful in oropharngeal, dermatological, urogenital tract and haematological problems [7] [8].

\section{Materials and Methods}

\subsection{Animal Grouping and Drug Administration}

A total of 36 adult male Wistar rats weighing $100 \mathrm{~g}-150 \mathrm{~g}$ were purchased at the experimental animal house of the department of Human Physiology, Ahmadu Bello University Zaria. Animals were maintained under normal laboratory conditions. Animals were maintained on pellets of growers mash and given access to water ad libitum. The study lasted for a period of thirty (30) days. Grouping and administration was done as follows:

Group I: Distilled water for 30 days (control) per oral (p.o). Group IIIsoniazid (27 mg/kg/day), p.o. for 30 days which served as toxic control. Group III-Isoniazid ( $27 \mathrm{mg} / \mathrm{kg} /$ day), p.o and Livolin ${ }^{\circledR} 20 \mathrm{mg} / \mathrm{kg}$ p.o for 30 days which served as positive control. Group IV-Isoniazid (27 mg/kg/day), p.o. and Byrsocarpus coccineus $200 \mathrm{mg} / \mathrm{kg}$ p.o for 30 days. Group V-Isoniazid (27 $\mathrm{mg} / \mathrm{kg} / \mathrm{day})$, p.o. and Byrsocarpus coccineus $400 \mathrm{mg} / \mathrm{kg}$ p.o for 30 days. Group VI-Isoniazid (27 mg/kg/day), p.o. and Byrsocarpus coccineus $800 \mathrm{mg} / \mathrm{kg}$ p.o for 30 days. Ethical approval was obtained from the ethical committee of Ahmadu Bello University, Zaria on animal handling, consistent with standard animal welfare guideline.

\subsection{Sample Collection}

\section{Plant collection and identification}

The plant was obtained from Nimbia Forest Reserve, Jema'a LGA; Kaduna State, Nigeria. Plant identification was done at the Herbarium Unit of the Department of Biological Sciences, Ahmadu Bello University, Zaria and a specimen Voucher (Voucher Number: 926) was collected for further reference.

Preparation of Aqueous Extract of B. coccineus

Fresh leaves of $B$. coccineus were air-dried until a constant weight was obtained. 
Aqueous extraction was done at the Basic Research Laboratory of the National Research Institute for Chemical Technology, Bassawa Zaria. The dried material was macerated in distilled water $(30 \mathrm{~g}$ in $3 \mathrm{~L})$ and refrigerated at $4^{\circ} \mathrm{C}$. The extract was decanted 24 hours later. The filtrate was then evaporated to dryness in an oven at $40^{\circ} \mathrm{C}$ to yield a dark brown powder (Akindele and Adeyemi, 2006). A portion of the extract was reconstituted in distilled waters and used for phytochemical analysis. The dried extract was weighed and reconstituted in distilled water $(\mathrm{pH}=6.8)$, just before administration to experimental animals, to obtain a concentration of 10 $\mathrm{mg} / \mathrm{ml}$ to enable administration of appropriate volumes based on the dose to be administered to the different treatment groups.

Blood sample collection

At the end of the experiment, after overnight fasting, the animals were euthanized and dissected; blood was collected through cardiac puncture, centrifuged at $3000 \mathrm{rpm}$ and used for the assessment of liver enzymes; alanine amino transferase, alkaline phosphatase and aspartate amino transferase. Liver tissues were harvested also and used for histological study.

\section{Liver tissue collection}

Liver tissue was harvested on the $30^{\text {th }}$ day from the experimental groups and used for histological study in the Department of Histopathology, Faculty of Medicine; Ahmadu Bello University Teaching Hospital, Zaria. The method of $\mathrm{H}$ and $\mathrm{E}$ staining technique was used which involved hydrating the tissue sections in descending grades of alcohol from 100\%, 95\%, 90\% and finally 70\% [9]. Each of these steps lasted three (3) minutes and the tissues were then washed in running tap water. The tissue were stained with haematoxylin for twenty five (25) minutes, washed with water and then differentiated in acid alcohol. The tissue were then counter stained with eosin and blued in Scott water. The tissues were hydrated with ascending grades of alcohol and cleared in xylene for three (3) changes in five (5) minutes each. The tissues were mounted with cover slips using a mounting media. The tissues were viewed under a light microscope and the photomicrographs taken.

\subsection{Quantitative Phytochemical Analysis}

\section{Alkaloid determination}

Five grams of the sample was weighed into a $250 \mathrm{ml}$ beaker and $200 \mathrm{ml}$ of $10 \%$ acetic acid in ethanol was added and covered and allowed to stand for $4 \mathrm{~h}$. This was filtered and the extract was concentrated on a water bath to one-quarter of the original volume. Concentrated ammonium hydroxide was added dropwise to the extract until the precipitation was complete. The whole solution was allowed to settle and the precipitated was collected and washed with dilute ammonium hydroxide and then filtered. The residue is the alkaloid, which was dried and weighed [10].

Flavonoid determination

Ten grams of the plant sample was extracted repeatedly with $100 \mathrm{ml}$ of $80 \%$ 
aqueous methanol at room temperature. The whole solution was filtered through whatman filter paper No $42(125 \mathrm{~mm})$. The filtrate was later transferred into a crucible and evaporated into dryness over a water bath and weighed to a constant weight [11].

\section{Saponin determination}

The method used was that of [12]. Twenty grams of samples powder was put into a conical flask and $100 \mathrm{ml}$ of $20 \%$ aqueous ethanol were added. The samples were heated over a hot water bath for $4 \mathrm{~h}$ with continuous stirring at about $55^{\circ} \mathrm{C}$. The mixture was filtered and the residue re-extracted with another $200 \mathrm{ml} 20 \%$ ethanol. The combined extracts were reduced to $40 \mathrm{ml}$ over water bath at about $90^{\circ} \mathrm{C}$. The concentrate was transferred into a $250 \mathrm{ml}$ separating funnel and $20 \mathrm{ml}$ of diethyl ether was added and shaken vigorously. The aqueous layer was recovered while the ether layer was discarded. The purification process was repeated. $60 \mathrm{ml}$ of n-butanol was added. The combined n-butanol extracts were washed twice with $10 \mathrm{ml}$ of $5 \%$ aqueous sodium chloride. The remaining solution was heated in a water bath. After evaporation the samples were dried in the oven to a constant weight and the saponin content was calculated as percentage.

\section{Determination of tannins}

Powdered extract $(0.5 \mathrm{~g})$ was extracted with $300 \mathrm{ml}$ of diethyl ether for 20 hours at room temperature. The residue was boiled for $2 \mathrm{~h}$ with $100 \mathrm{ml}$ of distilled water, and then allowed to cool, and was filtered. The extract was adjusted to a volume of $100 \mathrm{ml}$ in a volumetric flask. The content of tannins in the extract was determined colorimetrically using Folin-Denis reagent, and by measuring absorbance of the blue complex at $760 \mathrm{~nm}$, using tannic acid solution as a standard Solution [13].

\subsection{Liver Enzymes Analysis}

The serum liver enzymes, alanine aminotransferase (ALT), aspartate aminotransferase (AST) and alkaline phosphatase (ALP) were determined from the serum, using Agape Diagnostic kits, India.

Determination of serum aspartate aminotransferase (AST)

This was estimated by method as described by [14]. Exactly, $1000 \mu \mathrm{L}$ of the reagent will be added to $100 \mu \mathrm{L}$ of the samples and then mixed and incubated at $37^{\circ} \mathrm{C}$ for $1 \mathrm{~min}$. The change in absorbance of the sample was measured per minute spectrophotometerically at the wavelength of 590 .

Determination of serum alanine aminotransferase $(A L T)$

This was estimated by the method as described by [14]. Exactly, $1000 \mu \mathrm{L}$ of the reagent was added to $100 \mu \mathrm{L}$ of the samples and then mixed and incubated at $37^{\circ} \mathrm{C}$ for $1 \mathrm{~min}$. The change in absorbance of the sample was measured per minute.

Determination of serum alkaline phosphatase ( $A L P)$

This was estimated by method as described by [15]. Exactly, $0.5 \mathrm{~mL}$ of the reagent was added to $0.05 \mathrm{~mL}(500 \mu \mathrm{L})$ of the samples and then mixed and 
incubated at $37^{\circ} \mathrm{C}$ for $10 \mathrm{~min}$. The change in absorbance of the sample was measured per minute.

\section{Results and Discussion}

The result of this present study from Table 1 shows the percentages of tannins, saponin, alkaloids and flavonoids; $2.29 \%, 18.05 \%, 23.24 \%$ and $18.99 \%$ respectively, with the highest percentage present as alkaloids. Antioxidant property of plant products are mainly mediated by their content of phenolic compounds the examples of which include flavonoids, phenolic acids, tannins and phenolic diterpenes [16] [17] [18]. These could have played a part in the ameliorative action of the extract at $200 \mathrm{mg} / \mathrm{kg}$. Phytochemicals are the chemicals extracted from plants. These chemicals are classified as primary or secondary constituents, depending on their role in plant metabolism. Primary constituents include the common sugars, amino acids, proteins, purines and pyrimidines of nucleic acids, chlorophyll's etc. Secondary constituents are the remaining plant chemicals such as alkaloids (derived from amino acids), terpenes (a group of lipids) and phenolics (derived from carbohydrates) [19].

Serum liver enzymes are important markers of hepatotoxicity, with serum Alanine aminotransferase being more specific for acute hepatocyte injury while aspartate aminotransferase is located in the cells lining the bile ducts [20]. In Table 2, the serum aspartate aminotransferase (AST) was non-significantly increased $(\mathrm{P}>0.05)$ in the group treated with isoniazid indicating a possible acute injury to the hepatic bile ducts, this increase was reversed by treatment with

Table 1. Result of Phytochemical studies (Quantitative) of Brysocarpus coccineus (Conaraceae) aqueous extracts.

\begin{tabular}{cc}
\hline Phytochemicals & Percentage (\%) \\
\hline Tannins & 2.29 \\
Saponin & 18.05 \\
Alkaloid & 23.24 \\
Flavonoids & 18.99 \\
\hline
\end{tabular}

Table 2. Serum Aspartate amino transferase (AST) after 30 days of treatment with $B$. coccineus aqueous extracts in Isoniazid induced hepatotoxicity in adult male Wistar rats.

\begin{tabular}{cc}
\hline Grouping (Treatment) & Serum AST level (IU/L) \\
\hline Normal control (N.S $1 \mathrm{ml} / \mathrm{kg})$ & $50.38 \pm 4.41$ \\
Isoniazid $(27 \mathrm{mg} / \mathrm{kg})$ & $50.83 \pm 4.21$ \\
Livolin Forte $(20 \mathrm{mg} / \mathrm{kg})$ & $44.67 \pm 4.00$ \\
B. coccineus $(200 \mathrm{mg} / \mathrm{kg})$ & $45.00 \pm 2.61$ \\
B. coccineus $(400 \mathrm{mg} / \mathrm{kg})$ & $52.67 \pm 5.32$ \\
B. coccineus $(800 \mathrm{mg} / \mathrm{kg})$ & $56.00 \pm 2.19$ \\
\hline
\end{tabular}

NS $=$ Normal saline, $B$. coccineus $=$ Byrsocarpus coccineus. 
livolin forte which is a standard curative drug for treatment of drug induced hepatotoxicity and oxidative stress [21]. The decrease in the serum level of AST in the group treated with the extract at $200 \mathrm{mg} / \mathrm{kg}$ and the dose dependent increase in the AST levels in the groups treated with 400 and $800 \mathrm{mg} / \mathrm{kg}$ of the aqueous extracts $B$. coccineus may indicate that the extracts reverses the hepatotoxic effects of isoniazid at the low dose while potentiating the toxic effects at higher doses. This could have resulted from a possible metabolites formed during metabolism of extract which tends to have a deleterious effect on the hepatocytes.

In Table 3, there was a non-significant increase in serum ALT level in the Isoniazid treated group when compared to the normal control. This was however reversed in the groups treated with Livolin forte and $200 \mathrm{mg} / \mathrm{kg} \mathrm{B.} \mathrm{coc-}$ cineus suggesting a possible ameliorative property of the extract on hepatocytes damage. The presence of flavonoids in the extract could also have contributed indirectly through the formation of uric acid from polymerization of flavonoids. Uric acid is known to play a vital role as an antioxidant, and could have in this study ameliorated or obliterated lipid peroxidation hence aiding in the restoration of hepatocytes integrity.

Table 4 shows the result of serum alkaline phosphatase (ALP). There was a

Table 3. Serum Alanine amino transferase (ALT) after 30 days of treatment with B. coccineus aqueous extracts in Isoniazid induced hepatotoxicity in adult male Wistar rats.

\begin{tabular}{cc}
\hline Grouping (Treatment) & Serum ALT level (IU/L) \\
\hline Normal control (N.S $1 \mathrm{ml} / \mathrm{kg})$ & $54.17 \pm 3.97$ \\
Isoniazid $(27 \mathrm{mg} / \mathrm{kg})$ & $55.83 \pm 5.11$ \\
Livolin Forte $(20 \mathrm{mg} / \mathrm{kg})$ & $48.50 \pm 5.54$ \\
B. coccineus $(200 \mathrm{mg} / \mathrm{kg})$ & $50.83 \pm 3.37$ \\
B. coccineus $(400 \mathrm{mg} / \mathrm{kg})$ & $57.00 \pm 6.03$ \\
B. coccineus $(800 \mathrm{mg} / \mathrm{kg})$ & $59.83 \pm 2.79$ \\
\hline
\end{tabular}

NS $=$ Normal saline, $B$. coccineus $=$ Byrsocarpus coccineus.

Table 4. Serum Alkaline Phosphatase (ALP) after 30 days of treatment with B. coccineus aqueous extracts in Isoniazid induced hepatotoxicity in adult male Wistar rats.

\begin{tabular}{cc}
\hline Grouping (Treatment) & Serum ALP level (IU/L) \\
\hline Normal control (N.S $1 \mathrm{ml} / \mathrm{kg})$ & $84.17 \pm 7.93$ \\
Isoniazid $(27 \mathrm{mg} / \mathrm{kg})$ & $81.17 \pm 1.84$ \\
Livolin Forte $(20 \mathrm{mg} / \mathrm{kg})$ & $82.83 \pm 5.57$ \\
B. coccineus $(200 \mathrm{mg} / \mathrm{kg})$ & $95.17 \pm 6.07$ \\
B. coccineus $(400 \mathrm{mg} / \mathrm{kg})$ & $96.33 \pm 3.43$ \\
B. coccineus $(800 \mathrm{mg} / \mathrm{kg})$ & $107.17 \pm 5.98^{\mathrm{a}}$ \\
\hline
\end{tabular}

NS $=$ Normal saline, $B$. coccineus $=$ Byrsocarpus coccineus , superscript $=$ statistical significance at $(\mathrm{P}<$ $0.05)$. 
statistically significant $(P<0.05)$ increase in serum ALP in the $800 \mathrm{mg} / \mathrm{kg}$ extract treated group when compared to the control and the Isoniazid treated group. This significant increase could have resulted from the overwhelming of the hepatocytes due to the increased dosage of the extract. This could also have been from a possible deleterious metabolite formation from high dose administration of the extract, resulting in pathologies like lipid peroxidation of the hepatocytes, hence the leakage of the liver enzymes into circulation.

\section{Results of Histological Studies after 30 Days of Treatment with B. coccineus Aqueous Extracts in Isoniazid Induced Hepatotoxicity in Adult Male Wistar Rats}

Figure 1 shows the central vein and hepatocytes of normal liver tissue treated with distilled water, which served as the control. There was however evidence of sinusoidal dilatation in Figure 2 and Figure 3 but no ballooning of the hepatocytes, Figures 4-6 show absent ballooning of hepatocytes and/or sinusoidal dilatations. Histologic studies have been proven to be very important in depicting drug induced liver injury and the degree of this injury by showing disruptions in the basic liver architecture which corroborate with the biochemical changes observed. In this study, there were no visible indicators of hepatic tissue damage; which include balloon degeneration of hepatocytes, bridging necrosis, sinusoidal dilatation, fatty deposits, or vacuolated cytoplasm in all the treated groups; these features are usually seen in hepatitis induced by isoniazid. The liver parenchymal cells architecture appears intact with the central vein and sinusoids. This result could be due to the dosage administered or possibly the duration of drug administration which didn't allow for obvious features of hepatitis. Swelling with non-lipid cytoplasmic vacuolation of diffusely distributed hepatocytes is seen consistently after mild acute and sub-acute liver injury [22]. However, in this study there was no cytoplasmic vacuolation observed from the treated groups, this could be due to the duration of drug administration.

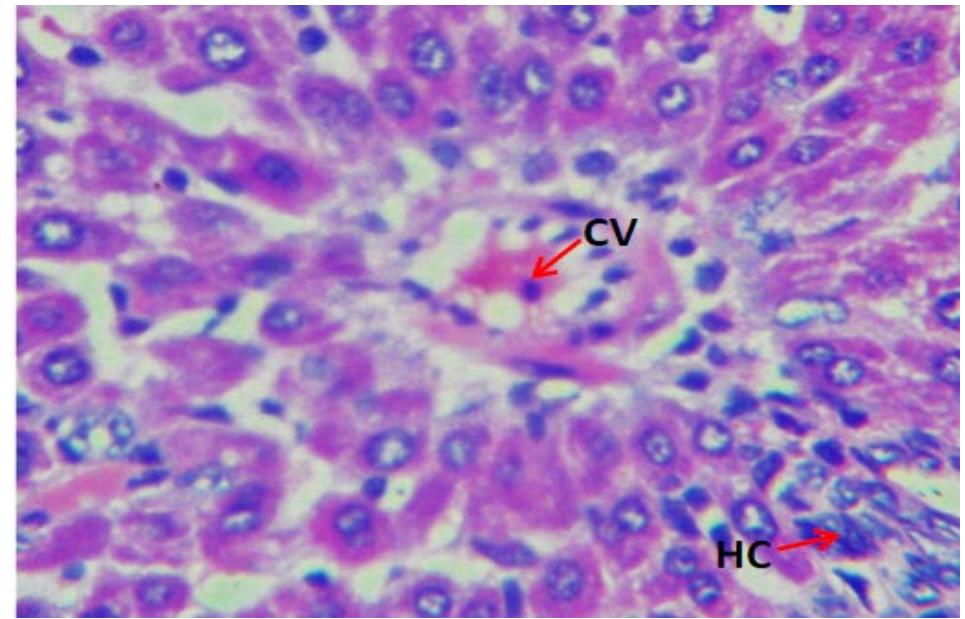

Figure 1. The photomicrograph sections of the liver from Wistar rats treated orally with distilled water for 30 days ( $\mathrm{H}$ and $\mathrm{E}, \times 400 . \mathrm{CV}=$ central vein, $\mathrm{HC}=$ hepatocyte). 


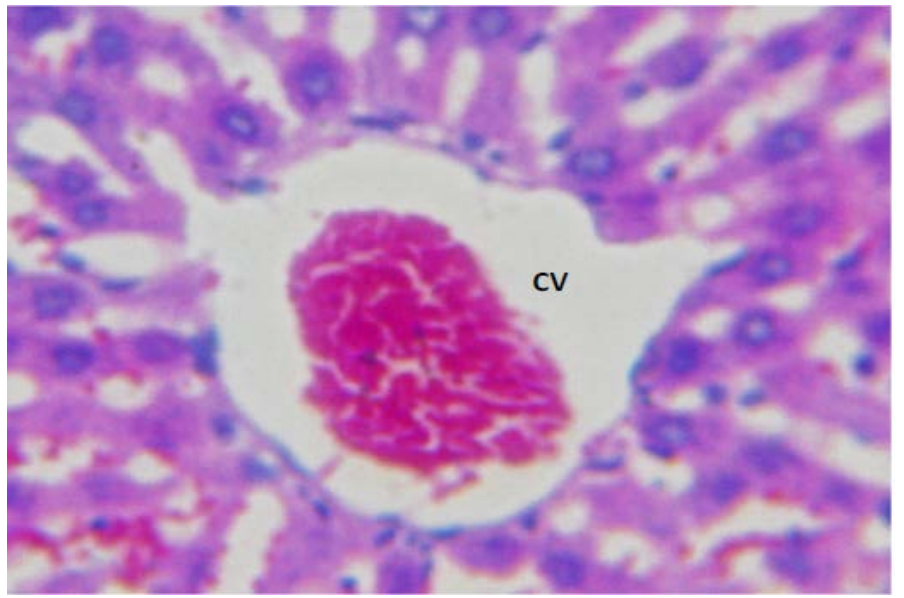

Figure 2. The photomicrograph sections of the liver from Wistar rats treated orally with Isoniazid for 30 days $(\mathrm{H}$ and $\mathrm{E}, \times 400 . \mathrm{H}$ and $\mathrm{E}, \times 400 . \mathrm{CV}=$ central vein, $\mathrm{HC}=$ hepatocyte).

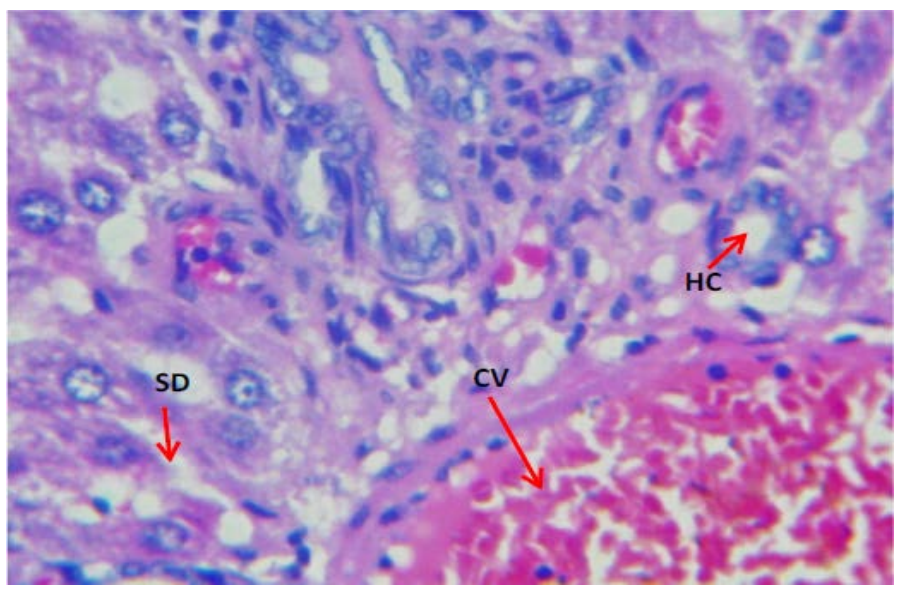

Figure 3. The photomicrograph sections of the liver from Wistar rats treated orally with Isoniazid and Livolin forte for 30 days $(\mathrm{H}$ and $\mathrm{E}, \times 400 . \mathrm{H}$ and $\mathrm{E}, \times 400 . \mathrm{CV}=$ central vein, $\mathrm{HC}=$ hepatocyte).

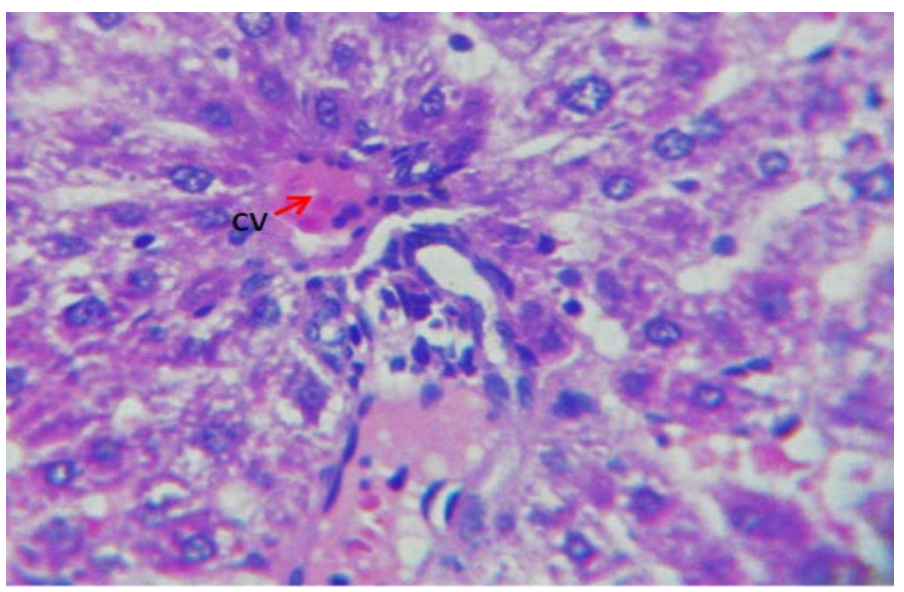

Figure 4. The photomicrograph sections of the liver from Wistar rats treated orally with Isoniazid and B. coccineus $(200 \mathrm{mg} / \mathrm{kg})$ for 30 days $(\mathrm{H}$ and $\mathrm{E}, \times 400 . \mathrm{CV}=$ central vein, $\mathrm{HC}=$ hepatocyte). 


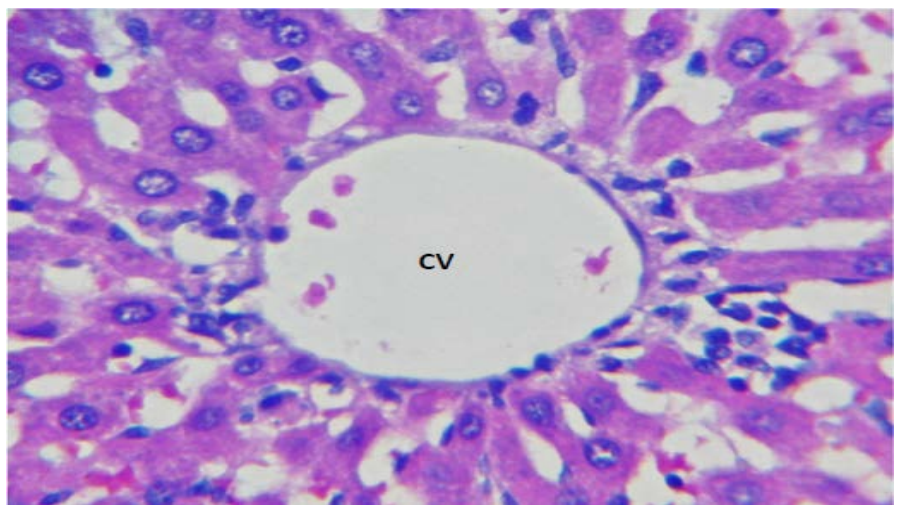

Figure 5. The photomicrograph sections of the liver from Wistar rats treated orally with Isoniazid and B. coccineus $(400 \mathrm{mg} / \mathrm{kg})$ for 30 days $(\mathrm{H}$ and $\mathrm{E}, \times 400 . \mathrm{CV}=$ central vein, $\mathrm{HC}=$ hepatocyte).

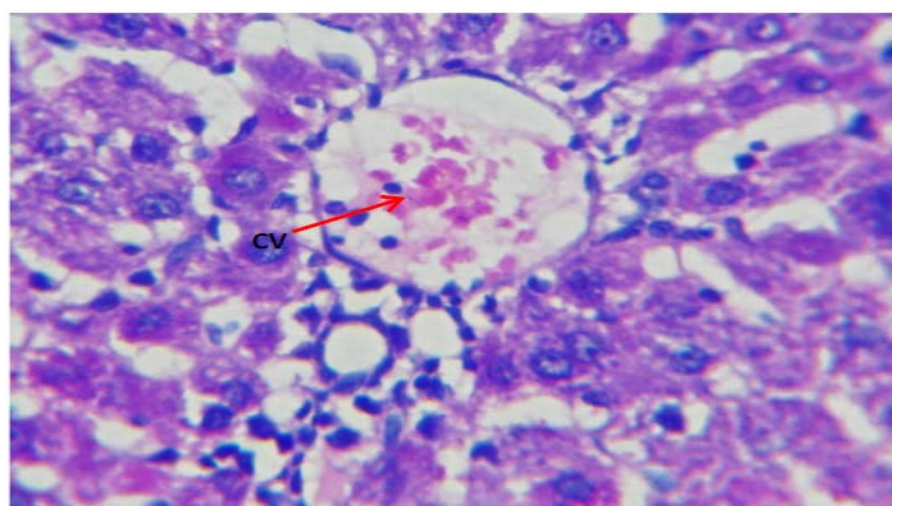

Figure 6. The photomicrograph sections of the liver from Wistar rats treated orally with Isoniazid and $B$. coccineus $(800 \mathrm{mg} / \mathrm{kg})$ for 30 days $(\mathrm{H}$ and $\mathrm{E}, \times 400 . \mathrm{CV}=$ central vein, $\mathrm{HC}=$ hepatocyte).

\section{Conclusion}

Brysocarpus coccineus contains some polyphenolic constituents, which are known to enable an extract with antioxidant potentials. However, this study showed that Brysocarpus coccineus at a high dose is hepatotoxic when administered orally for a period of thirty days.

\section{References}

[1] Huang, Y.S. (2007) Genetic Polymorphisms of Drug-Metabolising Enzymes and the Susceptibility to Antituberculosis Drug-Induced Liver Injury. Expert Opinion on Drug Metabolism and Toxicology, 3, 1-8. https://doi.org/10.1517/17425255.3.1.1

[2] Huang, Y.S. (2014) Review Article: Recent Progress in Genetic Variation and Risk of Antituberculosis Drug-Induced Liver Injury. Journal of the Chinese Medical Association, 77, 173.

[3] Ching, S. (2011) A Study of Genetic Polymorphism Underlying Idiosyncratic Hepatotoxicity Due to Anti-Tuberculosis Medications. A thesis submitted in partial fulfilment of the requirements for the Degree of Doctor of Philosophy, Newcastle University, Newcastle, 23-34.

[4] Gamaniel, K.S., Akah, P.A., Samson, A. and Wambebe, C.O. (1997) Evaluation of 
Nigerian Traditional Medicine: Effects of Gakani, a Herbal Anti-Asthmatic Drug. Journal of Ethnopharmacology, 55, 8792. https://doi.org/10.1016/S0378-8741(96)01475-4

[5] Wazis, C. H., Anuka, J.A., Timothy, S.Y., Zezi, A.U., Mohammed, G.T. and Hussaini, I.M. (2012) Acute Toxicity and in-Vivo Effects of Leaf Extracts of Byrsocarpus Coccineus Shum \& Thonn in Pregnant Rat Uterus. Journal of Applied Pharmaceutical Science, 2, 130-136. https://doi.org/10.7324/JAPS.2012.21224

[6] Dalziel, J.M. (1937) The Useful Plants of West Tropical Africa. A Crown Agent for Oversea Publication, London, 568-570.

[7] Akindele, A.J. and Adeyemi, O.O. (2006) Evaluation of the Antidiarrhoeal Activity of Byrsocarpus coccineus. Journal of Ethnopharmacology, 108, 20-25. https://doi.org/10.1016/j.jep.2006.03.038

[8] Amos, S., Binda, L., Kunle, O.F., Wambebe, C. and Gamaniel, K. (2002) Uterotonic Properties of the Ethanolic Extract of Byrsocarpus coccineus. Pharmaceutical Biology, 40, 33-38. https://doi.org/10.1076/phbi.40.1.33.5855

[9] Laporta, J., Peters, T.L., Merriman, K.E., Vezina, C.M. and Hernandez, L.L (2013) Serotonin (5-HT) Affects Expression of Liver Metabolic Enzymes and Mammary Gland Glucose Transporters during the Transition from Pregnancy to Lactation. PLoS ONE, 8, 57847. https://doi.org/10.1371/journal.pone.0057847

[10] Harbone, J.B. (1984) Phytochemical Methods. Capman and Hall, London, New York, Melbourne, Madras, 20-110. https://doi.org/10.1007/978-94-009-5570-7

[11] Boham, B.A. and Kocipai-Abyazan, R. (1974) Flavonoids and Condensed Tannins from Leaves of Hawaiian Vaccinium vaticulatum and $V$. calycinium. Pacific Science, 48, 458-463.

[12] Obdoni, B.O. and Ochuko, P.O. (2001) Phytochemical Studies and Comparative Efficacy of the Crude Extracts of Some Homostatic Plants in Edo and Delta States of Nigeria. Global Journal of Pure and Applied Science, 8, 203-208.

[13] Chanwitheesuk, A., Teerawutgulrag, A. and Rakariyatham, N. (2005) Screening of Antioxidant Activity and Antioxidant Compounds of Some Edible Plants of Thailand. Food Chemistry, 92, 491-497.

[14] Bergmeyer, H. and Walefeld, M. (1978) Kinetic Method for the Determination of TGO and TGP without Pyridoxal Phosphate. Clinica Chimica Acta, 24, 58.

[15] Bowers, G.N.J. and Mc-Comb, R.B. (1966) A Continuous Spectrophotometric Method for Measurement the Activity of Serum Alkaline Phosphatase. Clinical Chemistry, 12, 73-78.

[16] Hollman, P.C. and Arts, J.C. (2005) Polyphenols and Disease in Epidemiologic Studies. American Journal of Clinical Nutrition, 81, 317S-325S.

[17] Manach, C., Scalbert, A., Morand, C., Remesy, C. and Jimenez (2004) Polyphenols: Food Sources and Bioavailability. American Journal of Clinical Nutrition, 79, 727-747.

[18] Vaya, J. And Aviram, M. (2001) Nutritional Antioxidants: Mechanisms of Action, Analyses of Activities and Medical Applications. Current Medicinal Chemistry, 18, 99-117. https://doi.org/10.2174/1568013013359168

[19] Duduku, K., Rosalam, S. and Awang, B. (2007) Phytochemical Antioxidants for Health and Medicine-A Move towards Nature. Biotechnology and Molecular Biology Review, 1, 97-104.

[20] Benichou, C. (1990) Criteria of Drug-Induced Liver Disorders. Report of an International Consensus Meeting. Journal of Hepatology, 11, 272-276. 
[21] Olukiran, O.S., Akomolafe, R.O., Bamitale, K., Ajayi, A.O., Okonji, R.E. and Bejide, R.A. (2014) Protective and Curative Effects of Livolin Forte on Carbon Tetrachloride-Induced Liver Damage in Wistar Rats. Journal of Experimental and Integrative Medicine, 4, 57-65. https://doi.org/10.5455/jeim.310813.or.088

[22] Adams, D.H., Ju, C., Ramaiah, S.K., Uetrecht, J. and Jaeschke, H. (2010) Mechanisms of Immune-Mediated Liver Injury. Toxicological Sciences, 115, 307-321. https://doi.org/10.1093/toxsci/kfq009

Submit or recommend next manuscript to SCIRP and we will provide best service for you:

Accepting pre-submission inquiries through Email, Facebook, LinkedIn, Twitter, etc. A wide selection of journals (inclusive of 9 subjects, more than 200 journals)

Providing 24-hour high-quality service

User-friendly online submission system

Fair and swift peer-review system

Efficient typesetting and proofreading procedure

Display of the result of downloads and visits, as well as the number of cited articles Maximum dissemination of your research work

Submit your manuscript at: http://papersubmission.scirp.org/

Or contact aer@scirp.org 